\title{
Role of ghrelin in the pancreatic exocrine secretion via mitogen-activated protein kinase signaling in rats
}

\author{
Kyung-Hoon Lee ${ }^{1,2 \dagger}$, Jae-Sung Lee ${ }^{1,3 \dagger}$, Tao Wang $^{4}$, Jin-Ju Oh${ }^{5}$, Sanggun Roh ${ }^{6}$ and Hong-Gu Lee ${ }^{1,3^{*}}$
}

\begin{abstract}
Background: This study was performed to investigate the impact of exogenous ghrelin on the pancreatic a-amylase outputs and responses of pancreatic proteins to ghrelin that may relate to pancreatic exocrine.

Methods: Sprague-Dawley male rats (9 weeks old, $300 \pm 10 \mathrm{~g}$ ) were injected with ghrelin via intraperitoneal (i.p.) infusion at dosage of $0,0.1,1.0$ and $10.0 \mu \mathrm{g} / \mathrm{kg}$ body weight (BW), respectively. The plasma ghrelin and cholecystokinin (CCK) level were determined using enzyme immunoassay kit; the mRNA expression of ghrelin receptor (GHSR-1a) and growth hormone $(\mathrm{GH})$ receptor were assessed by reverse transcription PCR; the expressions of pancreatic a-amylase activity, extracellular-signal-regulated kinases (ERK), phosphorylated extracellular-signal-regulated kinases (pERK) and c-Jun N-terminal kinase (JNK) were evaluated by western blotting; moreover the responses of pancreatic proteins to ghrelin were analyzed using the two-dimensional gel electrophoresis system.
\end{abstract}

Results: The exogenous ghrelin (1.0 and $10.0 \mathrm{\mu g} / \mathrm{kg} \mathrm{BW}$ ) elevated the level of plasma ghrelin $(p<0.05)$, and suppressed the expression of pancreatic $a$-amylase at a dose of $10.0 \mu \mathrm{g} / \mathrm{kg} \mathrm{BW}(p<0.05)$. No difference in the level of plasma CCK was observed, even though rats were exposed to any dose of exogenous ghrelin. In addition, a combination of western blot and proteomic analysis revealed exogenous ghrelin $(10.0 \mu \mathrm{g} / \mathrm{kg} \mathrm{BW}$ ) induced increasing the JNK and ERK expressions $(p<0.05)$ and four proteins such as Destrin, Anionic trypsin-1, Trypsinogen, and especially eukaryotic translation initiation factor 3 in rat pancreas.

Conclusions: Taken together, exogenous ghrelin by i.p. infusion plays a role in the pancreatic exocrine secretion via mitogen-activated protein kinase signaling pathway.

Keywords: a-Amylase activity, Cholecystokinin, Ghrelin, Pancreatic exocrine, Sprague-Dawley rats

\section{Background}

Ghrelin is a peptide hormone that has been isolated from the stomach and plays important roles in the release of growth hormone $(\mathrm{GH})$, appetite stimulation and various physiological activities [1, 2]. Ghrelin receptor (GHSR-1 $\alpha$ ) detected in endocrine cells of the stomach or/and in pancreatic cells shows a number of actions in the intestines and in the pancreas. Intravenous administration of ghrelin in rats reduced the secretion of

\footnotetext{
* Correspondence: hglee66@konkuk.ac.kr

${ }^{\dagger}$ Equal contributors

${ }^{1}$ Department of Animal Science and Technology, College of Animal Bioscience and Technology, Konkuk University, Seoul 05029, South Korea ${ }^{3}$ Team of Educational Program for Specialists in Global Animal Science, Brain Korea 21 Plus Project, Konkuk University, Seoul 05029, South Korea Full list of author information is available at the end of the article
}

pancreatic enzymes stimulated by cholecystokinin (CCK) and the suppressible response of the pancreas to ghrelin is indirect and may be exerted at the level of intrapancreatic neurons [3]. On the other hand, central administration of ghrelin stimulated pancreatic exocrine secretion in conscious rats [4]. In addition, the ghrelin acts on dorsal vagal complex to stimulate pancreatic protein output [5]. Especially, ruminants have a limited ability for intestinal starch digestion of pancreatic $\alpha$ amylase [6]. Previous studies [7, 8] suggested that the supply of gastrointestinal hormones also can improve starch digestion in the bovine small intestine, showing that $\alpha$-amylase secretion from the pancreas for starch digestion is involved in gastrointestinal hormones, CCK and ghrelin. Such CCK and secretin were widely 
revealed that these things increased pancreatic $\alpha$ amylase secretion. However, the results of previous studies concerning the influence of ghrelin on pancreatic exocrine function are still controversial.

We therefore performed this study to determine the impacts of exogenous ghrelin, given intraperitoneal (i.p.) on plasma ghrelin, CCK level and pancreatic $\alpha$-amylase output in the Sprague-Dawley (SD) rats. In addition, the responses of pancreatic proteins to exogenous ghrelin were investigated using the two-dimensional gel electrophoresis (2-DE) system.

\section{Methods}

\section{Animals and management}

Nine-week-old SD male rats (Samtako Bio Korea Co. Ltd., Osan-si, Gyeonggi-Do, South Korea) with average body weights (BW) of $300 \pm 10 \mathrm{~g}$ were used for all experiments. Animals were housed at one cage per animal on a 12/12 h light/dark cycle (lights on at 08:00 h) and given access to food and water ad libitum.

\section{Sampling procedures}

Exogenous ghrelin (Acylated form; Bachem Americas, Inc., Torrance, CA, USA) was injected in rats by i.p. infusion at doses of $0,0.1,1.0$ and $10.0 \mu \mathrm{g} / \mathrm{kg} \mathrm{BW}$, respectively. One hour after the injection, each blood sample $(1 \mathrm{~mL})$ was collected from rat caudal vein once into heparined-tube and immediately centrifuged (3000 rpm, $15 \mathrm{~min}$ ) to obtain the plasma in all group. Aliquots of plasma were stored at $-80{ }^{\circ} \mathrm{C}$ till analyzed. Rats were then anesthetized via intramuscular injection of zoletil (Virbac, Carros, France) at a dose of $15.0 \mathrm{mg} / 300 \mathrm{~g} \mathrm{BW}$ and each pancreas, liver and pituitary tissue of rats were aseptically collected. All experimental procedures were in accordance with the Animal Care and Use Committee of Pusan National University (PNU-2012-0056).

\section{Determination of plasma ghrelin and CCK level}

Rat ghrelin peptide was obtained from Bachem Americas, Inc. (Torrance, CA, USA). Rat plasma ghrelin and CCK enzyme immunoassay kit were purchased from Phoenix Pharmaceuticals Inc. (Burlingame, CA, USA). All the measurements were done following the manufacturers' instruction.

\section{Ribonucleic acid (RNA) extraction and reverse transcription polymerase chain reaction (RT-PCR)}

RT-PCR was performed to assess the messenger RNA (mRNA) expression of ghrelin receptor (GHSR-1 $\alpha$ ) and GH receptor. Total RNA was individually extracted from the pancreas, liver and pituitary of rat given ghrelin $(10.0 \mu \mathrm{g} / \mathrm{kg} \mathrm{BW})$ using TRIzol Reagent (Invitrogen,
Carlsbad, CA, USA). First-strand complementary deoxyribonucleic acid was synthesized from $5 \mathrm{~g}$ of RNA and $1 \mathrm{~g}$ oligo (dT) primer with 250 units M-MLV reverse transcriptase (Invitrogen, Carlsbad, CA, USA) and then subjected to PCR amplification using gene specific primers. The PCR specific primers used in this study were 5'-GAGATCGCTCAGATCAGCCAGATCAGCCAGTAC3' (sense) and 5'-TAATCCCCAAACTGAGGTTCTGC-3' (anti-sense) for GHSR-1 $\alpha, 5^{\prime}$-GAAAGAATGCCCTGATTATGTC-3' (sense) and 5' ${ }^{\prime}$-TCATACTCCAGAATTATCCATCC-3' (anti-sense) for GH receptor. The RT-PCR conditions were 32 cycles of denaturation at $94{ }^{\circ} \mathrm{C}$ for $30 \mathrm{~s}$, annealing at $59.5^{\circ} \mathrm{C}$ for $30 \mathrm{~s}$ and elongating at $72{ }^{\circ} \mathrm{C}$ for $30 \mathrm{~s}$. The PCR products were resolved on a $1.5 \%$ agarose gel by electrophoresis.

\section{Western blot analysis}

Pancreatic tissues of rats given exogenous ghrelin $(10.0 \mu \mathrm{g} / \mathrm{kg} \mathrm{BW})$ were homogenized and suspended in lysis buffer containing $50 \mathrm{mM}$ Tris-hydrochloric acid $(\mathrm{HCl})(\mathrm{pH} 8.0), 1 \%$ sodium dodecyl sulfate, $0.25 \%$ sodium deoxycholate, $1 \mathrm{mM}$ ethylenediaminetetra acetic acid, and $1 \mathrm{X}$ protease inhibitor (GE Healthcare, Piscataway, NJ, USA). Extracts were incubated for $30 \mathrm{~min}$ on ice and stirred every $5 \mathrm{~min}$, after which the samples were centrifuged at $14,000 \mathrm{rpm}$ for $30 \mathrm{~min}$ at $4{ }^{\circ} \mathrm{C}$. The protein concentrations were determined by a BCA Protein Assay (Pierce, Rockford, IL, USA). For western blot of pancreatic $\alpha$-amylase, extracellular-signal-regulated kinases (ERK), phosphorylated extracellular-signal-regulated kinases (pERK) and c-Jun N-terminal kinase (JNK), $30 \mu \mathrm{g}$ protein was separated by $12.5 \%(w / v)$ sodium dodecyl sulfate polyacrylamide gel electrophoresis (SDS-PAGE), after which the samples were blotted onto nitrocellulose membranes. The membranes were blocked overnight at $4{ }^{\circ} \mathrm{C}$ in TBST (20 mM Tris- $\mathrm{HCl}, \mathrm{pH}$ 7.6), $137 \mathrm{mM}$ sodium chloride, $0.01 \%$ Tween 20 ) containing $5 \%$ skim milk and then incubated for $3 \mathrm{~h}$ at $4{ }^{\circ} \mathrm{C}$ with the following primary antibodies: Rabbit polyclonal to pancreatic $\alpha$-amylase $(1: 16,000,54 \mathrm{kDa})$, rabbit polyclonal to ERK (sc-94, $1: 1000,42 / 44 \mathrm{kDa})$, rabbit polyclonal to SAPK/JNK (\#9252, 1:1000, 46/54 kDa) (Cell signaling Technology, Danvers, MA, USA). The samples were then washed three times with 1X TBST, after which they were incubated with the appropriate secondary antibody for $3 \mathrm{~h}$ at $4{ }^{\circ} \mathrm{C}$ : Goat polyclonal to rabbit IgG-HRP (ab6721, 1: 10,000, Abcam, Cambridge, MA, USA). The proteins on the membrane were visualized using and enhanced chemiluminescence system plus detection kit (GE Healthcare, Piscataway, NJ, USA), after which they were exposed to X-ray film (Fujifilm Co., Tokyo, Japan) for 1-3 min. The films were then scanned and the bands were quantified using the Image J 1.43 software (http://rsb.info.nih.gov/ij/download.html). 


\section{2-DE analysis}

2-DE was performed with proteins of pancreatic tissue of rats given exogenous ghrelin $(10.0 \mu \mathrm{g} / \mathrm{kg} \mathrm{BW})$. Briefly, protein samples were diluted into isoelectric focusing (IEF) buffer containing $6 \mathrm{M}$ urea, $2 \mathrm{M}$ thiourea, 1\% 3-[(3-cholamidopropyl) dimethylammonium]-1-propanesulfonate, $0.002 \%$ bromophenol blue, $0.5 \%$ pharmalyte ( $\mathrm{pH} 3-10 \mathrm{NL}$ ) and $65 \mathrm{mM}$ dithiothreitol (DTT). Then $100 \mu \mathrm{g}$ protein samples of control or treatment were loaded on Immobiline DryStrip gels (pH 3-10NL, 18-cm; GE Healthcare, Piscataway, NJ, USA) for rehydration for $12 \mathrm{~h}$ at $20{ }^{\circ} \mathrm{C}$. The IEF procedures were performed using an IEF electrophoresis unit (GE Healthcare, Piscataway, NJ, USA) following the manufacturer's protocols. The following voltage program was used after the $12 \mathrm{~h}$ rehydration: linear ramp from 500 to $1000 \mathrm{~V}$ over $2 \mathrm{~h}$, then a constant voltage of $8000 \mathrm{~V}$ for $7 \mathrm{~h}$ to give a total of $56,000 \mathrm{~V} \mathrm{~h}$. After focusing, gel strips were equilibrated in a solution containing $50 \mathrm{mM}$ Tris- $\mathrm{HCl}$ ( $\mathrm{pH} 8.8$ ), $6 \mathrm{M}$ urea, 2\% sodium dodecyl sulfate, $30 \%$ glycerol, $0.002 \%(w / v)$ bromophenol blue and DTT for $15 \mathrm{~min}$, followed by incubation in the same solution but replacing DTT with $135 \mathrm{mM}$ iodoacetamide for another $15 \mathrm{~min}$. After that the equilibrated strips were inserted into SDS-PAGE gels (18-cm, 12\%). SDS-PAGE was performed using an Ettan DALT 2-D gel system (GE Healthcare, Piscataway, NJ, USA). Upon completion, gels were stained using a PluseOne ${ }^{\mathrm{\tau м}}$ Silver Staining Kit (GE Healthcare, Piscataway, NJ, USA). The silver-stained gels were scanned using an Umax scanner (Power Look 2100XL, UMAX Technologies Inc., Dallas, TX, USA). Scanned gel images were processed by Proteomweaver ${ }^{\mathrm{Tm}}$ 2-D Analysis Software (Definiens AG, Munich, Germany).

\section{Statistical analysis}

All values are presented as means \pm standard error of the mean (SEM). The group mean values were compared with an independent sample $t$-test (SPSS 14.0,
Chicago, IL, USA). A probability less than 0.05 was considered to be statistically significant.

\section{Results}

In this study, the i.p. infusion of ghrelin $(0,0.1,1.0$ or $10.0 \mu \mathrm{g} / \mathrm{kg} \mathrm{BW})$ significantly elevated plasma concentrations of ghrelin $(p<0.05)$ (Fig. 1a). Nevertheless increasing plasma ghrelin, no significant differences in the plasma CCK level were observed (Fig. 1b). Western blot analysis revealed that increasing plasma ghrelin decreased pancreatic $\alpha$-amylase expression (Fig. 2). Based on our observation, the ghrelin receptor (GHSR-1 $\alpha$ ) does not exist (Fig. 3B); however, we found that the $\mathrm{GH}$ receptor mRNA expression was observed in the pancreatic tissue of rats given exogenous ghrelin $(10.0 \mu \mathrm{g} / \mathrm{kg}$ BW, Fig. 3A). We found that the expression of JNK and ERK in ghrelin-treated group $(10.0 \mu \mathrm{g} / \mathrm{kg}$ BW) was higher than that in untreated group (Fig. 4). Moreover, four spots (Destrin, Anionic trypsin-1, Trypsinogen and Eukaryotic translation initiation factor 3) ranging from 6 to $200 \mathrm{kDa}$ were detected by 2-DE, and differently expressed in the pancreatic protein map (Fig. 5).

\section{Discussion}

In the previous study, we showed that increasing plasma CCK level did not significantly increase pancreatic $\alpha$ amylase expression [9]. However, it differed from those of other previous studies $[4,5,10,11]$. We therefore hypothesized that the mechanism related to pancreatic exocrine secretion may have down-regulating factor by exogenous ghrelin. We believed that GH might be one of these factors. Studies by Anderson and Hellman et al. $[12,13]$ reported that $\mathrm{GH}$ decreases insulin secretion via mitogen-activated protein (MAP) kinase signaling and has a paracrine effect on endocrine secretion. Thus, we investigated the levels of plasma ghrelin and CCK by i.p. infusion with exogenous ghrelin $(0,0.1,1.0$ and $10.0 \mu \mathrm{g} /$ a
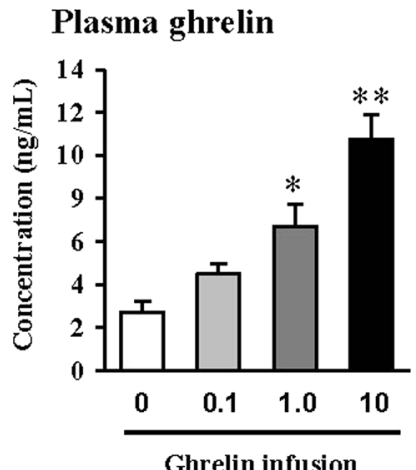

b Plasma CCK

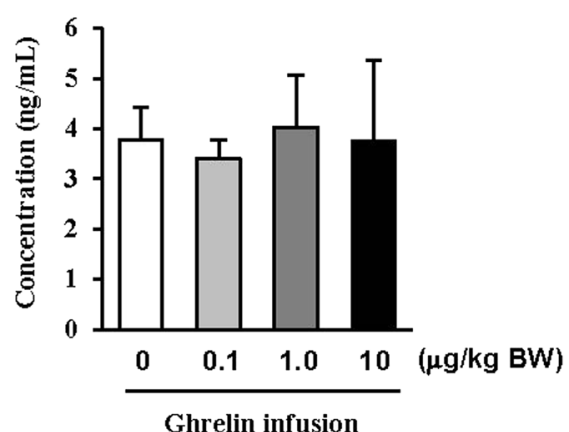

Fig. 1 Concentration of plasma ghrelin (a) and cholecystokinin (CCK) (b) in rat exposure to exogenous ghrelin $(0,0.1,1.0$ and $10.0 \mu \mathrm{mg} / \mathrm{kg}$ BW). The values are expressed as the average with SEM $(n=4)$. Asterisk shows significant difference with the ghrelin-untreated group $\left({ }^{*} p<0.05,{ }^{* *} p<0.01\right)$ 


\section{Pancreatic $\alpha$-amylase}

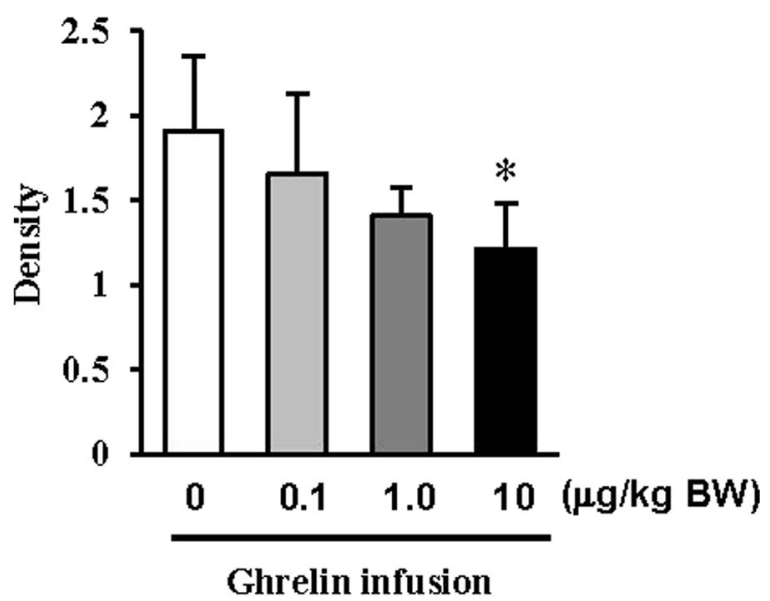

Fig. 2 Western blot analysis of a-amylase expressions in tissues of pancreas of rat exposure to exogenous ghrelin $(0,0.1,1.0$ and $10.0 \mu \mathrm{g} /$ $\mathrm{kg} \mathrm{BW})$. The values are expressed as the average with SEM $(n=4)$. Asterisk shows significant difference with the ghrelin-untreated group $\left({ }^{*} p<0.05\right)$

$\mathrm{kg}$ BW). The i.p. infusion of ghrelin at the dose of 1.0 and $10.0 \mu \mathrm{g} / \mathrm{kg} \mathrm{BW}$ significantly increased plasma concentrations of ghrelin $(p<0.05)$ whereas no significant differences in the plasma CCK level was observed (Fig. 1a, b). The western blot analysis of pancreatic $\alpha$-amylase activity (Fig. 2) suspected that ghrelin may regulate exocrine secretion through other signals; direct or indirect actions not releasing CCK. Thus, we assumed the signal pathway related to pancreatic $\alpha$-amylase secretion either ghrelin's direct action or other factors. To further elucidate the mechanism related to pancreatic $\alpha$-amylase secretion, ghrelin receptor (GHSR-1 $\alpha$ ) and GH receptor mRNA expression were examined using RT-PCR (Fig. 3). In addition, the results indicated ghrelin may indirectly influence the pancreatic $\alpha$-amylase secretion via releasing $\mathrm{GH}$.

Based on this finding, we hypothesized that ghrelin may decrease pancreatic $\alpha$-amylase secretion via the release of GH. Therefore, we determined whether $\mathrm{GH}$ releases affected pancreatic $\alpha$-amylase secretion. Studies reported that MAP kinase signaling concerned with GH affects the pancreatic endocrine secretion and paracrine effect to exocrine secretion [12,13]. Thus, we confirmed JNK and ERK expressions, one of MAP kinase signal factors. As shown in the Fig. 4, the expression of JNK and ERK in ghrelin-treated group $(10.0 \mu \mathrm{g} / \mathrm{kg} \mathrm{BW})$ was higher than that in untreated group $(0 \mu \mathrm{g} / \mathrm{kg} \mathrm{BW})$ $(p<0.05)$. It has been reported that expression of JNK and ERK is stimulated by GH [14]. We therefore speculated that these factors were expressed by ghrelin stimulating the release of GH. Studies showed that MAP kinase was found to exert anti-insulin effect by inducing the release of $\mathrm{GH}$. This anti-insulin activity inhibits pancreatic exocrine secretion [12, 14]. Synthetically, we suggested that increasing expression of factors in the MAP kinase signaling by GH induced the decrease in the pancreatic exocrine secretion. The response of pancreatic proteins to exogenous ghrelin $(10.0 \mu \mathrm{g} / \mathrm{kg} \mathrm{BW})$ by i.p. infusion was analyzed by $2-\mathrm{DE}$ in order to get a better understanding of the mechanisms involved in the ghrelin exocrine secretion through GH signal (Fig. 5). Four spots were up-regulated by exogenous ghrelin infusion compared to untreated group $(0 \mu \mathrm{g} / \mathrm{kg}$ BW $)$. Among these spots, proteins of eukaryotic translation initiation factor 5A-1 (eIF5A) and destrin were of

a Growth hormone receptor

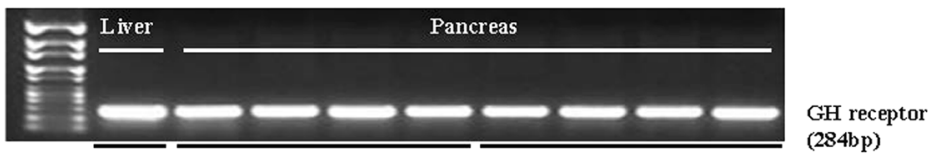

10

0

$10 \mu \mathrm{g} / \mathrm{kg}$ BW of ghrelin infusion

b

Ghrelin receptor

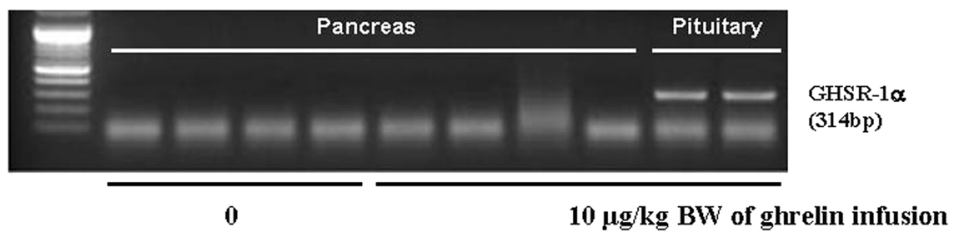

Fig. 3 mRNA expressions of pancreatic ghrelin receptor (GHSR-1a) and growth hormone (GH) receptor in tissues of pancreas, liver, and pituitary of rat exposure to exogenous ghrelin (0 and $10.0 \mu \mathrm{g} / \mathrm{kg} \mathrm{BW}$ ) using RT-PCR 
a Western blotting

0

10

$(\mu \mathrm{g} / \mathrm{kg} \mathrm{BW}$ of ghrelin infusion)

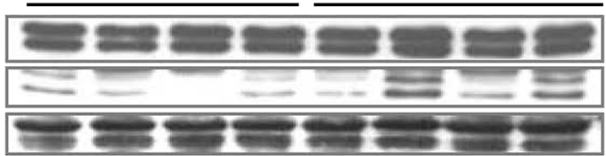

ERK $1 / 2(42 / 44 \mathrm{kDa})$

PERK $1 / 2(42 / 44 \mathrm{kDa})$

b

Protein intensity

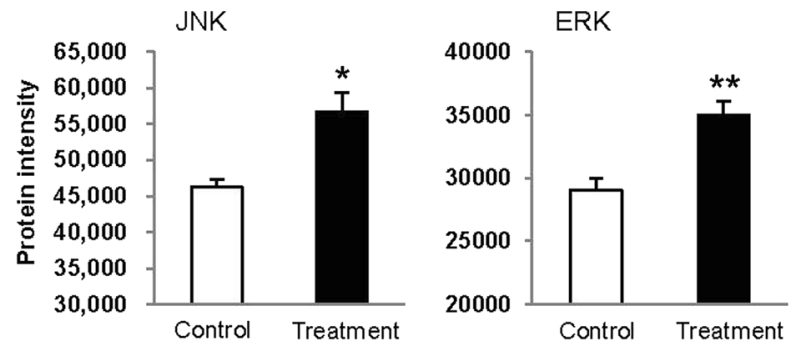

Fig. 4 Level of pancreatic extracellular-signal-regulated kinases (ERK), phosphorylated extracellular-signal-regulated kinases (pERK) and c-Jun N-terminal kinase (JNK) expression by using western blotting. Protein sample from pancreatic tissue of rats treated with ghrelin (10.0 $\mu \mathrm{g} / \mathrm{kg}$ BW) was analyzed by western blot (a) and their bands were determined by pixel intensity analysis using NIH Image J (b). The values are expressed as the average with SEM $(n=4)$. Asterisk shows significant difference with the ghrelin-untreated group $\left(^{*} p<0.05,{ }^{* *} p<0.01\right)$
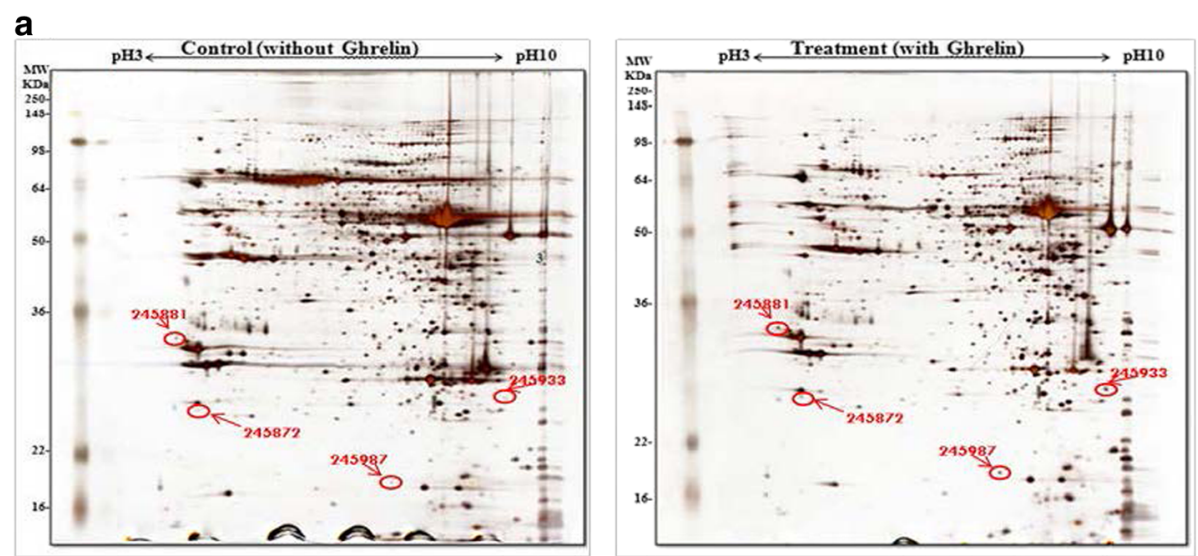

\section{b}

\begin{tabular}{|c|c|c|c|c|}
\hline Spot & Control & Treatment & Expression ${ }^{1}$ & Protein name \\
\hline 245987 & $=$ & $\mathbf{0}$ & 5.69 & Destrin \\
\hline 245933 & 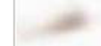 & $\mathbf{z}$ & 4.44 & Anionic trypsin-1 \\
\hline 245872 & 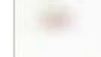 & e & 2.27 & Eukaryotic translation initiation factor 3 \\
\hline 245881 & $=$ & e & 1.93 & Trypsinogen \\
\hline
\end{tabular}

Fig. 5 Identification of differentially altered protein spots in rat pancreas by ESI/Q-TOF MS. Representative silver-stained 2-DE images of the normal rat pancreas (left) and $10.0 \mathrm{\mu g} / \mathrm{kg}$ BW ghrelin-infused rat pancreas (right) (a). The spots that differentially expressed proteins in rat pancreas were identified by ESI/Q-TOF MS (b). ${ }^{1)}$ The values of the protein expression were presented as the ghrelin-treated group against ghrelin-untreated group 
particular interest due to that destrin is involved in decreasing insulin secretion $[14,15]$. Our study found that the destrin expression was elevated by releasing $\mathrm{GH}$ response to exogenous ghrelin, indicating that exogenous ghrelin by i.p. infusion could be acted as a modulator for insulin secretion. eIF5A is involved in biosynthesis of pancreatic enzyme by increasing plasma CCK level [16]. In contrast, our study showed exogenous ghrelin had no influence on plasma CCK level (Fig. 1b). Considering our present reports, ghrelin may have effect on pancreatic exocrine secretion via other factors in releasing CCK. When the effects of exogenous ghrelin by i.p. infusion on pancreatic exocrine secretion was done artificially, we have to consider other factors like GH related to insulin synthesis as involving in the CCK secretion and activation of cholinergic vago-vagal enteropancreatic reflex.

\section{Conclusion}

The result suggested exogenous ghrelin by i.p. infusion in rats modulates the secretion of pancreatic exocrine via MAP kinase signaling, such as JNK and ERK proteins. However, the proteins related to functional study mechanism were still uncompleted. Thus, some following functional study of proteins will be investigated in the near future.

\begin{abstract}
Abbreviations
$\%:$ Percent; ${ }^{\circ} \mathrm{C}$ : Celsius; 2-DE: Two-dimensional gel electrophoresis; BW: Body weight; CCK: Cholecystokinin; elF5A: Eukaryotic translation initiation factor 5A-1; ERK: Extracellular-signal-regulated kinases; g: Gram; GH: Growth hormone; H: Hour; i.p.: Intraperitoneal; JNK: c-Jun N-terminal kinase; Kg: Kilogram; M: Molar; MAP: Mitogen-activated protein; Mg: Milligram; Min: Minute; mM: Millimolar; mRNA: messenger RNA; PCR: Polymerase chain reaction; pERK: Phosphorylated extracellular-signal-regulated kinases; rpm: Revolutions per minute; RT: Reverse transcription; S: Second; SD: Sprague-Dawley; SDS-PAGE: Sodium dodecyl sulfate polyacrylamide gel electrophoresis; SEM: Standard error of the mean; Mg: Microgram
\end{abstract}

\section{Acknowledgements}

This study was supported by grants from the Agricultural Biotechnology Development Program (No. 313020-04), Korea Institute of Planning and Evaluation for Technology in Food, Agriculture, Forestry and Fisheries, Republic of Korea.

\section{Funding}

This study was supported by grants from the Agricultural Biotechnology Development Program (No. 313020-04), Korea Institute of Planning and Evaluation for Technology in Food, Agriculture, Forestry and Fisheries, Republic of Korea.

\section{Availability of data and materials}

Authors approved the data and materials availability.

\section{Authors' contributions}

KHL mainly carried out this study and drafted the manuscript. JSL contributed reagents/materials/analysis tools, prepared figures and/or Tables. TW performed the experiments, contributed reagents/materials/analysis tools, prepared figures and/or tables, reviewed drafts of the paper. JJO and SGR revised the drafts of the paper. HGL conceived and designed the experiments, reviewed drafts of the paper. All authors read and approved the final manuscript.

\section{Competing interests}

The authors declare that they have no competing interests.

\section{Ethics approval}

All experimental procedures involving animals were conducted in accordance with the Animal Care and Use Committee of Pusan National University (PNU-2012-0056).

\section{Publisher's Note}

Springer Nature remains neutral with regard to jurisdictional claims in published maps and institutional affiliations.

\section{Author details}

'Department of Animal Science and Technology, College of Animal Bioscience and Technology, Konkuk University, Seoul 05029, South Korea. ${ }^{2}$ Research Department, Korea Industrial Co., Ltd., Pusan 46978, South Korea. ${ }^{3}$ Team of Educational Program for Specialists in Global Animal Science, Brain Korea 21 Plus Project, Konkuk University, Seoul 05029, South Korea. ${ }^{4}$ College of Animal Science and Technology, Jilin Agricultural University, Changchun 130118, China. ${ }^{5}$ Natural Product Clinical Research Center, Clinical Research Center, Pusan National University School of Medicine, Busan 49241, South Korea. 'Laboratory of Animal Physiology, Graduate School of Agricultural Science, Tohoku University, Sendai 981-8555, Japan.

Received: 10 January 2017 Accepted: 12 June 2017

Published online: 24 July 2017

\section{References}

1. Gualillo O, Lago F, Gomez-Reino J, Casanueva FF, Dieguez C. Ghrelin, a widespread hormone: insights into molecular and cellular regulation of its expression and mechanism of action. FEBS Lett. 2003;552:105-9.

2. Kojima M, Kangawa K. Ghrelin, an orexigenic signaling molecule from the gastrointestinal tract. Curr Opin Pharmacol. 2002;2:665-8.

3. Zhang W, Chen M, Chen X, Segura BJ, Mulholland MW. Inhibition of pancreatic protein secretion by ghrelin in the rat. J Physiol. 2001;537:231-6.

4. Sato N, Kanai S, Takano S, Kurosawa M, Funakoshi A, Miyasaka K. Central administration of ghrelin stimulates pancreatic exocrine secretion via the vagus in conscious rats. The Jpn J Physiol. 2003;53:443-9.

5. Li Y, Wu X, Zhao Y, Chen S, Owyang C. Ghrelin acts on the dorsal vagal complex to stimulate pancreatic protein secretion. Am J Physiol Gastrointest Liver Physiol. 2006;290:G1350-8.

6. Harmon D, Taylor C. Factors influencing assimilation of dietary starch in beef and dairy cattle. In: Proc Southwest Nutr Conf; 2005. p. 55-66.

7. Richards C, Swanson K, Paton S, Harmon D, Huntington G. Pancreatic exocrine secretion in steers infused postruminally with casein and cornstarch. J Anim Sci. 2003:81:1051-6.

8. Taniguchi K, Huntington GB, Glenn BP. Net nutrient flux by visceral tissues of beef steers given abomasal and ruminal infusions of casein and starch. J Anim Sci. 1995;73:236-49.

9. Lee $\mathrm{K}-\mathrm{H}$, Wang $\mathrm{T}$, Jin $\mathrm{Y}-\mathrm{C}$, et al. Identification of proteins involved in the pancreatic exocrine by exogenous ghrelin administration in SpragueDawley rats. J Anim Sci Technol. 2014;56:1.

10. Broglio F, Prodam F, Me E, et al. Ghrelin: endocrine, metabolic and cardiovascular actions. J Endocrinol Investig. 2005;28:23-5.

11. Ghelardoni S, Carnicelli V, Frascarelli S, Ronca-Testoni S, Zucchi R. Ghrelin tissue distribution: comparison between gene and protein expression. J Endocrinol Investig. 2006;29:115-21.

12. Anderson NG. Growth hormone activates mitogen-activated protein kinase and $\mathrm{S} 6$ kinase and promotes intracellular tyrosine phosphorylation in 3T3-F442A preadipocytes. Biochem J. 1992;284(Pt 3):649-52.

13. Hellman B, Gylfe E, Grapengiesser E, Dansk H, Salehi A. Insulinoscillationer-en kliniskt betydelsefull rytmik. Diabetesläkemedel bör öka den pulsatila komponenten av insulinfrisättningen: Insulin oscillations-clinically important rhythm. Antidiabetics should increase the pulsatile component of insulin release. Lakartidningen. 2007;104:2236-9.

14. Foster CM, Shafer JA, Rozsa FW, et al. Growth hormone promoted tyrosyl phosphorylation of growth hormone receptors in murine 3T3-F442A fibroblasts and adipocytes. Biochemistry. 1988;27:326-34.

15. Al-Khalili L, de Castro BT, Östling J, et al. Profiling of human myotubes reveals an intrinsic proteomic signature associated with type 2 diabetes. Adv Integr Med. 2014;2:25-38.

16. Bragado MJ, Tashiro M, Williams JA. Regulation of the initiation of pancreatic digestive enzyme protein synthesis by cholecystokinin in rat pancreas in vivo. Gastroenterology. 2000;119:1731-9. 